\title{
Media Sosial dan Pembelajaran: Study Efektifitas Instagram dalam Pembelajaran Bahasa Inggris
}

\author{
${ }^{1}$ Ni Made Lisma Martarini
}

\section{${ }^{2}$ Kadek Ayu Riska Yulianti}

\author{
${ }^{3}$ Ni Nyoman Ayu J. Sastaparamitha
}

\section{${ }^{123}$ Program Studi Teknik Informatika STMIK-STIKOM Indonesia}

\author{
1lismamartarini@gmail.com \\ 2ayuriskaa@gmail.com \\ 3ayusasta@stiki-indonesia.ac.id
}

\begin{abstract}
Abstrak
Salah satu mata kuliah dasar yang harus dipelajari oleh mahasiswa sesuai dengan jurusan yang mereka pilih adalah Bahasa Inggris. English for Spesific Purposes (ESP) adalah kemampuan bahasa Inggris yang dikhususkan untuk tujuan tertentu. Writing skill adalah salah satu skill yang memiliki capaian kurang maksimal dilihat dari nilai hasil pembelajaran mahasiswa STMIK-STIKOM Indonesia. Di era seperti sekarang ini dimana teknologi digital menjadi konsumsi dan kebutuhan vital dari masyarakat, media sosial adalah salah satu hal yang amat disukai para anak muda. Berangkat dari hal tersebut maka penelitian ini akan menggunakan media sosial khususnya Instagram sebagai media pembelajaran dan dapat memotivasi mahasiswa dalam belajar bahasa Inggris. Teknik pengumpulan data yang digunakan adalah hasil tulisan baik pre-test maupun post-test, serta observasi, dan dokumentasi. Untuk mengetahui keefektifan media sosial Instagram sebagai sarana belajar akan dinilai dari hasil kuisioner dari mahasiswa. Sampel dari penelitian ini merupakan 30 mahasiswa jurusan Teknik Informatika, STMIK-STIKOM Indonesia. Tahapan dari proses pengambilan data dalam penelitian ini meliputi; (1) observasi kepada subjek penelitian ini, (2) tahap sosialisasi dengan mahasiswa tentang bagaimana tata cara pembelajaran dengan menggunakan media sosial ini khususnya dengan menggunakan Instagram, (3), pelaksanaannya penelitian ini, pada tahap ini mahasiswa akan diberikan materi pada awalnya dimana mereka tidak hanya menerima materi tersebut tetapi harus mencari materi pendukung lainnya, serta berdiskusi dan menerima saran serta masukan dari dosen maupun teman- temannya, (4)Tahapan terakhir adalah tahap pelaksanaan penggunaan Instagram sebagai sarana diskusi serta untuk tempat posting hasil kerja mahasiswa.
\end{abstract}

Kata Kunci: Writing, Teks Prosedur, Instagram

\section{Pendahuluan}

Proses pembelajaran bahasa asing tidaklah mudah. Salah satunya bagi mahasiswa non-bahasa yang mempelajari bahasa asing. Bahasa Inggris sebagai bahasa asing atau English as Foreign Language (EFL) adalah terminologi yang terjadi di Indonesia dimana bahasa Inggris digunakan selain bahasa Ibu atau dalam hal ini bahasa daerah adalah bahasa pertama dan bahasa Indonesia adalah bahasa kedua dan bahasa Inggris sebagai 
bahasa asing. Mengingat pentingnya penguasaan bahasa Inggris dalam komunikasi internasional, Pemerintah telah mengintegrasikan pembelajaran bahasa Inggris dari jenjang pendidikan dasar sampai pada pendidikan tinggi. Bahasa Inggris merupakan mata kuliah dasar yang harus dipelajari oleh mahasiswa sesuai dengan jurusan yang mereka pilih. English for Spesific Purposes (ESP) adalah kemampuan bahasa Inggris yang dikhususkan untuk tujuan tertentu. Keterampilan ini meliputi 4 skill yaitu, mendengarkan (listening), berbicara (speaking), membaca (reading), dan juga menulis (writing). Dari hasil survey yang dilaksanakan pada semester sebelumnya dan melihat capaian nilai mahasiswa dari ke 4 keterampilan tersebut, terlihat bahwa keterampilan listening dan reading dari siswa mendapatkan nilai yang cukup bagus yaitu mencapai rata-rata 80.00 sedangkan nilai speaking (berbicara) mahasiwa berada di rata-rata 75 dan skill menulis (writing) mahasiswa berada pada rata-rata 50.00. dari data tersebut dapat disimpulkanan bahwa keterampilan menulis mahasiswa masih kurang dan perlu untuk ditingkatkan lagi.

Menciptakan pembelajaran yang menarik dan juga merangsang kreatifitas keterampilan berpikir tingkat tinggi (HOTS) mutlak dilakukan para pendidik guna dapat memaksimalkan capaian tujuan pembelajaran. Pengajar dituntut untuk selalu berinovasi dan menerapkan metode, strategi serta media pembelajaran yang sesuai dengan minat, profil dan juga karakteristik dari mahasiswanya. Selain itu pemilihan materi yang kontekstual juga menjadi pertimbangan dalam pembelajaran yang akan membuat pembelajaran menjadi lebih bermakna dan akhirnya meningkatkan pemahaman mahasiswa. Seiring perkembangan teknologi, ternyata berimbas pada proses pembelajaran di kelas, mahasiswa yang merupakan generasi yang tumbuh bersama teknologi atau sering disebut generasi $\mathrm{Z}$ memiliki kefasihan dalam penggunaan teknologi seperti gadget dan laptop. Menurut Santrock (2007:20) "Masa remaja sebagai periode transisi perkembangan antara masa kanak-kanak dengan masa dewasa yang melibatkan perubahan-perubahan biologis, kognitif, dan sosio-emosional". Kreativitas siswa yang dilakukan pada saat belajar sangat banyak ragamnya, menurut Nasution (1994:150), jenis kreativitas belajar siswa meliputi (1) Visual activities. (2) Oral activities. (3) Listening activities. (4) Writing activities. (5) Drawing activities. (6) Motor activities. (7) Emotional activities. Perkembangan kreativitas remaja sangat erat kaitannya dengan perkembangan kognitif karena kreativitas merupakan wujud dari kerja kognitif. Dengan pemanfaatan teknologi yang dikombinasikan dengan pembelajaran tentu akan memaksimalkan capaian tujuan pembelajaran. Integrasi teknologi dalam pembelajaran bahasa juga telah banyak digunakan dan terbukti efektif dalam meningkatkan keterampilan dan hasil belajar.

Menurut Rahmawati (2016) dewasa ini manusia lebih sering berkomunikasi melalui internet, karena memudahkan berinteraksi dan berkomunikasi tanpa batas. Media sosial sebagai salah satu media yang banyak digunakan oleh sebagian besar orang termasuk mahasiswa ternyata dapat pula dimanfaatkan dalam pembelajaran. Hasil survey yang dilakukan sebelumnya menunjukkan bahwa 100 persen mahasiswa di salah satu kelas memiliki akun media sosial yang aktif mereka gunakan. Data juga menunjukkan bahwa mahasiswa menghabiskan lebih dari 10 jam perhari untuk bermain media sosial entah itu update status, upload story/video/dan lainnya. Dengan memperhatikan kecendrungan dari mahasiswa yang aktif menggunakan media sosial maka penulis ingin mengetahui bagaimana efektifitas dari pengintegrasian pembelajaran menggunakan media sosial yang dilakukan oleh mahasiswa.

Berdasarkan data di atas maka penelitian ini memiliki tujuan untuk mengetahui efektifitas penggunaan media sosial dalam pembelajaran bahasa Inggris dalam 
meningkatkan keterampilan menulis teks prosedur. Penelitian ini menggunakan pola tahapan yang meliputi observasi, sosialisasi penggunaan media sosial sebagai media pembelajaran, langkah-langkah pembelajaran dan pengambilan data.

\section{Kerangka Teori}

\section{Teks Prosedur}

Teks prosedur merupakan teks yang menjelaskan langkah-langkah dalam melakukan sesuatu. Langkah tersebut harus sesuai dengan runtutan yang benar sehingga mencapai tujuan apa yang ingin dicapai. Teks prosedur ini biasanya berbentuk cara ataupun tutorial membuat sesuatu atau mengerjakan sesuatu. Tujuan dari teks ini adalah agar memudahkan para pembaca atau pendengar untuk melakukan sesuatu. Biasanya teks ini mengandung suruhan atau perintah di dalamnya (Wardirman, 2008)

Struktur dari teks prosedur;
a. tujuan,
b. bahan dan alat,
c. langkah langkah,
d. penutup.

Pertama adalah tujuan; yang dimaksud di sini adalah hal apa yang ingin kamu lakukan atau capai. Kedua adalah bahan dan alat; disini kalian harus menulis atau menyebutkan apa saja yang diperlukan dalam melakukan atau mengerjakan sesuatu tersebut. Yang ketiga adalah langkah-langkah; pada tahap ini merupakan tahap yang paling penting yaitu harus menyebutkan langkah-langkah dalam mengerjakan hal yang diinginkan secara berurutan sehingga mencapai awal tujuan yang ingin dicapai. Yang terakhir merupakan penutup yang berisi penekanan pada keuntungan melakukan sesuatu.

2. Instagram sebagai Media Pembelajaran

Pembelajaran bukan hanya menyampaikan informasi atau pengetahuan saja, melainkan mengkondisikan pembelajar untuk belajar, karena tujuan utama pembelajaran adalah pembelajar itu sendiri (Munir, 2012). Interaksi dalam proses belajar mengajar mutlak diperlukan untuk mencapai apa yang diinginkan. Dalam pembelajaran penggunaan media pembelajaran yang relevan serta tepat digunakan untuk mendukung proses pembelajaran akan membantu mahasiswa untuk mencapai tujuan belajarnya tercapai secara maksimal. Peran pengajar sangatlah vital dalam hal pemilihan media pembelajaran. Pengajar dituntut untuk bisa kreatif serta inovatif dalam memilih media yang tepat dan disesuaikan dengan kondisi, profil belajar, serta tentunya menarik dan memotivasi mahasiswa untuk belajar.

Teknologi pembawa pesan yang dapat digunakan untuk keperluan pembelajaran adalah media pembelajaran, ini merupakan salah satu alat untuk menyampaikan materi pembelajaran. Media pembelajaran termasuk teknoloi perangkat keras dalam bentuk sarana komunikasi. Jadi, media pembelajaran merupakan sesuatu yang dapat merangsang perhatian dan minat para peserta didik sehingga dapat membantu tercapainya target atau tujuan pembelajaran. Alasan paling mendasar untuk menggunakan Instagram sebagai media pembelajaran adalah karena peserta didik sudah terbiasa menggunakan Instagram (Rusman,dkk, 2011).

Peneliti bisa dengan mudah menggunakan akun ini karena hampir semua mahasiswa sudah mempunyai akun untuk masuk ke Instagram. Kepopuleran yang mereka miliki dan dapatkan di media sosial sangat berpengaruh terhadap apa yang akan 
mereka unggah nantinya (Sesriani,dkk, 2019). Instagram memberikan peluang yang luar biasa untuk pembelajaran bahasa bagi guru dan siswa. Instagram sebagai salah satu media sosial yang sangat popular di Indonesia dan tentunya di dunia memiliki jutaan users atau pengguna yang aktif di setiap detiknya. Kepopuleran media sosial ini tentunya dapat dimanfaatkan oleh pengajar dalam memanfaatkannya tidak hanya sebagai pemberi pesan kepada khalayak publik namun lebih dari itu media sosial ini dapat kita manfaatkan sebagai media pembelajaran Bahasa Inggris yang menarik dan juga efektif memotivasi peserta didik menurut (Aydin, 2014 \& Campos, 2015).

Instagram menyediakan cara baru untuk peserta didik belajar bahasa dan budaya secara kritis, selain itu juga membantu peserta didik untuk merefleksikan proses pembelajaran bermakna (Chun dkk, 2016). Instagram sendiri memiliki banyak fitur dimana para penggunanya dapat membagikan cerita mereka melalui instastory dan feed mereka. Para pengguna dapat membagikan foto maupun video yang mereka ingin bagikan di akun mereka guna memperlihatkan apa yang sedang mereka rasakan, perbuat ataupun laksanakan. Tentu saja ini sangat bisa mendukung untuk dimanfaatkan sebagai media pembelajaran bahasa Inggris. Hal ini dapat dikaitkan dengan kegiatan dalam penggunaan media sosial ini dimana ketika para pengguna akan membagikan video ataupun foto, mereka harus memberikan kalimat dibawahnya untuk menjelaskan apa yang mereka ingin bagikan. Tentu saja bahasa sangat berguna disini.

\section{Metode}

Metode penelitian yang digunakan merupakan metode penelitian tindakan kelas. Yang menjadi sampel dalam penelitian ini adalah mahasiswa semester II tahun ajaran 2020/2021 sebanyak 30 mahasiswa. Teknik pengumpulan data yang digunakan adalah hasil tulisan baik pretest maupun postest, serta observasi, dan dokumentasi. Untuk mengetahui keefektifan Instagram sebagai sarana belajar akan dinilai dari hasil quisioner dari mahasiswa.

Tahap awal merupakan observasi kepada subjek penelitian ini. Observasi telah dilaksanakan dan memperlihatkan hasil yang kurang memuaskan. Mereka hanya sekedar menulis tanpa mencari referensi lain dan tidak melakukan proof reading. Mereka hanya sekedar mengumpulkan tugas mereka. Pada siklus I diawali dengan tahap sosialisasi dengan mahasiswa bagaimana tentang tata cara pembelajaran dengan menggunakan media sosial ini khususnya dengan menggunakan Instagram. Selanjutnya adalah pelaksanaan penelitian, mahasiswa akan diberikan materi dimana mereka tidak hanya menerima materi tersebut tetapi harus mencari dan mengeksplorasi materi pendukung dari sumber belajar lain yang bisa mereka cari tentang teks prosedur, serta berdiskusi dan menerima saran serta masukan dari dosen maupun teman-temannya. Tahapan terakhir adalah tahap pelaksanaan yang langsung menggunakan Instagram sebagai sarana diskusi serta hasil dari tahap terakhir penelitian ini. Pada siklus II, metode pelaksanaannya adalah sama dengan siklus I namun perbedaannya terdapat pada topik materi teks prosedur yang diberikan serta fitur media sosial Instagram yang dimanfaatkan oleh mahasiswa, dimana pada siklus II mahasiswa memanfaatkan fitur story atau feed pada Instagram dalam mempublikasikan tulisan mereka tentang teks prosedur. 


\section{Hasil}

Setelah menjalani proses pembelajaran menggunakan Instagram yang dimana merupakan sosial media yang banyak sekali digunakan oleh mahasiswa, hasil latihan menulis mahasiswa mengalami peningkatan. Hal ini dapat dilihat dari hasil tabel berikut ini.

\begin{tabular}{|l|l|l|l|l|}
\hline No & Informasi & $\begin{array}{l}\text { Sebelum } \\
\text { menggunakan } \\
\text { Instagram }\end{array}$ & $\begin{array}{l}\text { Sesudah } \\
\text { Menggunakan } \\
\text { Instagram } \\
\text { (Siklus I) }\end{array}$ & $\begin{array}{l}\text { Sesudah } \\
\text { Menggunakan } \\
\text { Instagram } \\
\text { (Siklus I) }\end{array}$ \\
\hline 1 & Rata- rata Nilai & 41.66 & 72.33 & 75.66 \\
\hline 2 & Skor tertinggi & 75.00 & 80.00 & 81.33 \\
\hline 3 & Skor terendah & 45.00 & 60.00 & 65.00 \\
\hline 4 & $\begin{array}{l}\text { Persentase nilai } \\
\text { C,D }\end{array}$ & $65.00 \%$ & $40.00 \%$ & $43.00 \%$ \\
\hline 5 & $\begin{array}{l}\text { Persentase nilai } \\
\text { A,B }\end{array}$ & $35.00 \%$ & $60.00 \%$ & $67.00 \%$ \\
\hline
\end{tabular}

Table 1. Hasil Penilaian

Berdasarkan tabel di atas masih ada mahasiswa yang belum tuntas pada saat pembelajaran ini berlangsung. Tabel menunjukkan nilai rata-rata hasil tulisan mahasiswa, skor tertinggi, dan skor terendah. Jumlah mahasiswa yang mendapatkan nilai A dan B mengalami kenaikan dari sebelum proyek dan setelah proyek. Adapun jumlah mahasiswa yang mencapai $C$ dan $D$ mengalami penurunan menjadi setengahnya dari sebelum proyek yang dapat juga dilihat pada tabel 1. Nilai mahasiswa meningkat sedemikian rupa setelah diterapkannya gaya pembelajaran yang berbasis media sosial ini. Dari hasil proyek ini sangat berpengaruh kepada gaya belajar siswa dan tentu saja pada pada hasil tulisan mereka. Dengan menggunakan media sosial dimana tulisan mereka dibaca oleh orang banyak mereka lebih berhati-hati dalam mengerjakan serta meningkatkan minat belajar mereka.

Hasil rata-rata dari tulisan mereka atau writing skill mereka juga turut meningkat. Hal ini terlihat dari hasil pekerjaan mereka yang di posting di Instagram dan dianalisa menggunakan rubrik penilaian. Rubrik penilaian diadaptasi dari Marhaeni, dkk (2017) yang bisa dilihat pada tabel 2 berikut ini;

\begin{tabular}{|l|l|l|l|}
\hline No & Komponen & $\begin{array}{l}\text { Sebelum menggunakan } \\
\text { Instagram }\end{array}$ & $\begin{array}{l}\text { Sesudah Menggunakan } \\
\text { Instagram (Siklus I) }\end{array}$ \\
\hline 1 & Isi karangan (Content) & 64.66 & 75.66 \\
\hline 2 & Organisasi Ide (organization) & 70.16 & 81.33 \\
\hline 3 & $\begin{array}{l}\text { Penggunaan kosakata } \\
\text { (Vocabulary) }\end{array}$ & 85.66 & 76.00 \\
\hline 4 & $\begin{array}{l}\text { Penggunaan Tata Bahasa } \\
\text { (Grammar) }\end{array}$ & 50.00 & 90.00 \\
\hline 5 & $\begin{array}{l}\text { Penggunaaan mekanika ejaan } \\
\text { dan tanda baca (Mechanism) }\end{array}$ & 70.00 & 706 \\
\hline
\end{tabular}

Tabel 2. Hasil rata-rata nilai siswa berdasarkan rubrik penilaian. 
Tabel 2 di atas menunjukkan bahwa adanya peningkatan dan kehati-hatian mahasiswa dalam menulis ketika akan di share di media sosial masing-masing, ini terlihat dari pencapaian rata-rata nilai tugas mahasiswa. Isi karangan atau isi dari pembahasan yang mereka buat di teks prosedur yang mana lebih tepatnya langkah-langkah untuk membuat atau mengerjakan sesuatu berada pada angka 75.66 , kemudian cara mengungkapkan ide atau membuat langkah-langkah tersebut lebih kreatif dan meningkat di angka 81.33. Penggunaan dan pemilihan kata dalam tulisan mereka juga tidak monotone lagi hal ini dilihat dari nilai rata-rata dari subyek tersebut mencapai 80.00. Penggunaan tata bahasa di dalam Bahasa Inggris meningkat di angka 76.66. Mahasiswa juga lebih berhati-hati terhadap ejaan serta tanda baca yang dipakai, nilai dalam mechanism ini mencapai 90.00

Minat belajar di penelitian ini diukur dalam 2 cara. Pertama adalah melihat seberapa banyak mahasiswa mengumpulkan tugas mereka sesuai dengan ketentuan yang diberikan. Pada pembelajaran konvensional, dimana pada saat pandemic covid-19 berlangsung kampus menggunakan media online untuk pembelajaran, Google Classroom merupakan media konvensional yang digunakan di sini. Ketika mahasiswa mengumpulkan tugas mereka dengan mengunggah file mereka di kelas tersebut dan hanya dilihat oleh dosen mereka masing-masing. Namun ketika menggunakan Instagram sebagai tempat mengumpulkan tugas mahasiswa lebih berhati-hati dan yang mengumpulkan tugas meningkat. Hal ini dapat dilihat dalam diagram berikut ini;

Diagram 1. Hasil perbandingan metode

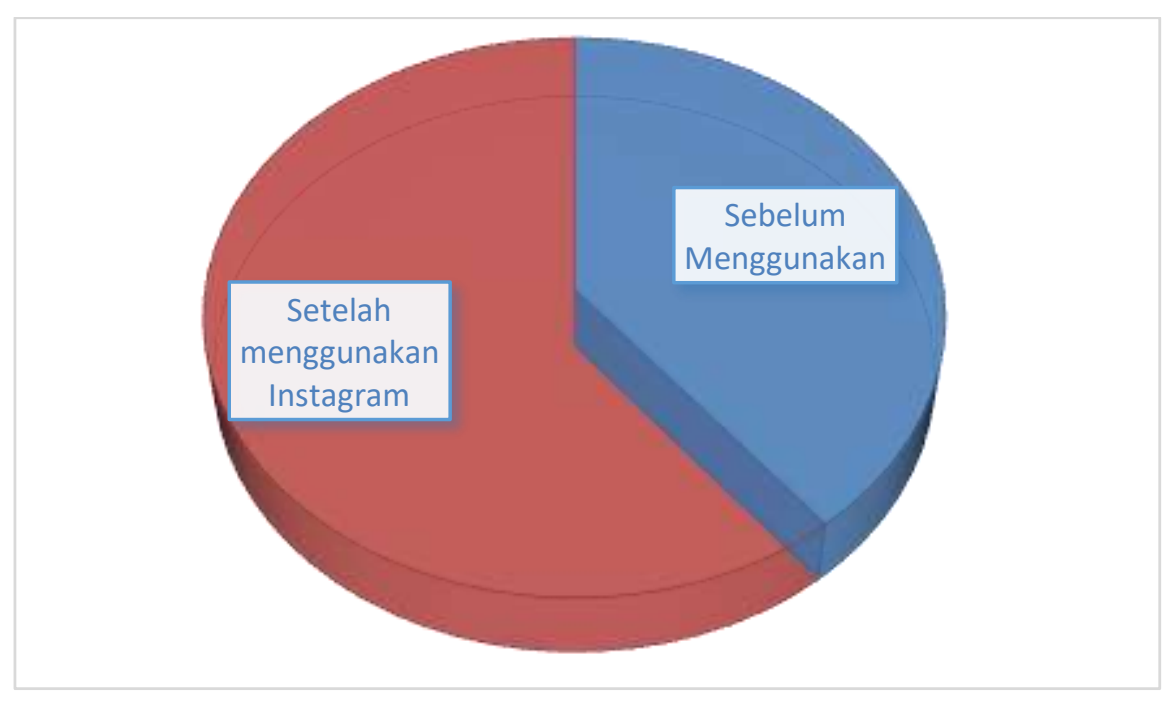

Diagram di atas menunjukkan sebelum pembelajaran dilaksanakan dengan menggunakan Instagram sebagai media pengumpulan tugas, mahasiswa yang mengumpulkan tugas hanya $52 \%$ dari 30 mahasiswa. Namun berbeda halnya setelah menggunakan media sosial sebagai media, yang mengumpulkan lebih dari $92 \%$ dari 30 mahasiswa.

Pengukuran minat dan motivasi siswa yang kedua dengan menggunakan quisioner. 30 mahasiswa yang terpilih menjadi sample mengisi survey terkait pendapat mahasiswa tentang pembelajaran berbasis Instagram ini. Mahasiswa diberikan lima pernyataan yang kemudian dijawab dengan memilih "ya" jika mereka setuju dengan pernyataan yang diajukan, memilih "biasa saja" jika mereka tidak yakin dengan jawaban mereka, dan 
memilih "tidak" jika mereka tidak setuju dengan pernyataan yang di ajukan. Hasil survey dpat dilihat pada tabel 3.

\begin{tabular}{|l|l|l|l|l|}
\hline No & Pertanyaan & Tidak & $\begin{array}{l}\text { Biasa } \\
\text { saja }\end{array}$ & Ya \\
\hline 1 & $\begin{array}{l}\text { Pembelajaran bahasa Inggris dengan menggunakan } \\
\text { Instagram menyenangkan. }\end{array}$ & 2 & 4 & 24 \\
\hline 2 & $\begin{array}{l}\text { Pembelajaran menggunakan media sosial membuat saya } \\
\text { ikut serta dalam proses pembelajaran bahasa Inggris. }\end{array}$ & 0 & 3 & 27 \\
\hline 3 & $\begin{array}{l}\text { Proses pembelajaran menggunakan Instagram membuat } \\
\text { saya lebih memahami bagaimana menulis teks prosedur } \\
\text { dengan hati-hati }\end{array}$ & 1 & 5 & 24 \\
\hline 4 & $\begin{array}{l}\text { Pembelajaran menggunakan media sosial membuat saya } \\
\text { sangat memperhatikan hasil dari tugas yang saya } \\
\text { kerjakan. }\end{array}$ & 0 & 3 & 27 \\
\hline 5 & $\begin{array}{l}\text { Pembelajaran bahasa Inggris dengan metode yang baru ini } \\
\text { sangat membuat saya termotivasi dalam belajar. }\end{array}$ & 0 & 1 & 29 \\
\hline
\end{tabular}

Tabel 2. Hasil survey motivasi belajar

Dari tabel diatas dapat dilihat bahwa sebanyak 80\% mahasiswa setuju metode ini menyenangkan. Sebanyak 90\% mahasiswa menyatakan mereka ikut serta dalam pembelajaran ini. Sebanyak $80 \%$ mahasiswa lebih memahami pembelajaran dengan metode ini. 90\% mahasiswa mengatakan lebih berhati-hati mengerjakan tugas karena akan di upload ke media sosial, serta 96\% mahasiswa mengatakan termotivasi mengikuti pembelajaran ini.

\section{Simpulan}

Hasil data dan fakta yang ada setelah penerapan proyek efektifitas media sosial khususnya Instagram dalam pembelajaran teks prosedur, maka penulis dapat menarik kesimpulan sebagai berikut: (1)mahasiswa menjadi lebih termotivasi dan senang dalam mengikuti pembelajaran (2)meningkatkan keterampilan menulis mahasiswa dalam bahasa Inggris khususnya dalam teks prosedur, (3)pembelajaran ini berkontribusi meningkatkan motivasi mahasiswa terhadap pembelajaran bahasa Inggris, (4)Pembelajaran ini dapat meningkatkan kewaspadaan siswa dalam mengerjakan tugas.

\section{Ucapan Terima Kasih}




\section{Daftar Pustaka}

Aydin, S. 2014. Foreign language learners' interactions with their teachers on Facebook. System, 42(1), 155-163. https://doi. org/10.1016/j.system.2013.12.001

Chun, D., Smith, B., \& Kern, R. 2016. Technology in language use, language teaching, and language learning. Modern Language Journal, 100, 64-80. https://doi.org/10.1111/modl.123 02

Lodya Sesriyani, Nur Najibah Sukmawati. 2019. Analisis Penggunaan Instagram sebagai Media Pembelajaran Bahasa Inggris Pada Program Studi Pendidikan Ekonomi; Eduka Jurnal Pendidikan, Hukum dan Bisnis.

Marhaeni, A.A.I.N, dkk. 2017. Asesmen Autentik dalam Pembelajaran Bahasa Inggris. Depo: Rajawali Pres.

Munir. 2012. Pembelajaran Jarak Jauh, Bandung: Alfabeta.

Nasution. 1994. Membina Kreativitas Siswa dalam Belajar. Jakarta: Balai Pustaka.

Rahmawati, Dewi. 2016. Pemilihan dan Pemanfaatan Instagram Sebagai Media Komunikasi Pemasaran. Online. Skripsi. Universitas Islam Negeri Sunan Kalijaga Yogyakarta : tidak di terbitkan.

Rusman., Deni Kurniawan., Cepi Riyana. 2011. Pembelajaran Berbasis Teknologi Informasi dan Komunikasi. Jakarta : PT Rajagrafindo Persada.

Santrock, J. W. 2007. Perkembangan Anak Remaja. Jakarta.

Wardiman, Artono. 2008. "English in Focus". Jakarta. Pusat Perbukuan Departemen Pendidikan Nasional. 